\title{
Pengaruh Tarif Progresif, Kualitas Pelayanan, Sosialisasi Perpajakan dan Pengetahuan Perpajakan Pada Kepatuhan Wajib Pajak
}

\author{
Luh Putu Cintya Wijayanti ${ }^{1}$ \\ I Made Sukartha ${ }^{2}$
}

${ }^{1}$ Fakultas Ekonomi dan Bisnis Universitas Udayana (Unud), Bali, Indonesia email: tyaainchaa97@gmail.com / Telp: 082339696884

${ }^{2}$ Fakultas Ekonomi dan Bisnis Universitas Udayana (Unud), Bali, Indonesia

\begin{abstract}
ABSTRAK
Pajak merupakan sumber penerimaan terbesar suatu Negara, khususnya Indonesia.Dalam mencapai tingkat kepatuhan wajib pajak dan mempertahankan tingkat kepatuhan meupakan isu yang menjadi perhatian baik di Negara maju maupun Negara berkembang.Penelitian ini dilakukan di Kantor SAMSAT Kabupaten Bangli dengan menggunakan ukuran sampel sebesar 397 orang dengan metode stratified random sampling yaitu dengan memperhatikan tingkatan (strata) pada elemen populasi. Adapun teknik analisis data yang digunakan dalam penelitian ini yaitu analisis regresi linier berganda. Hasil penelitian menemukan bahwa tarif progresif berpengaruh positif pada kepatuhan wajib pajak. Kualitas pelayanan berpengaruh positif pada kepatuhan wajib pajak. Sosialisasi perpajakan berpengaruh positif pada kepatuhan wajib pajak. Pengetahuan perpajakan wajib pajak berpengaruh positif pada kepatuhan wajib pajak. Penelitian ini diharapkan dapat menajadi motivasi bagi kantor samsat untuk dapat meningkatkan fasilitas fisik maupun non-fisik untuk meningkatkan kepatuhan wajib pajak.

Kata kunci: tarif progresif, kualitas pelayanan, sosialisasi perpajakan, pengetahuan wajib pajak, kepatuhan
\end{abstract}

\begin{abstract}
Tax is the largest source of revenue for country, especially Indonesia. In achieving the level of tax compliance and maintaining the level of compliance is an issue of concern in both developed and developing countries. This research was conducted at the SAMSAT Office Bangli Regency by using a sample size of 397 people with stratified random sampling method that is by observing the level (strata) on the population element. The data analysis technique used in this study is the multiple linear regression analysis. The results of the study found that progressive rates had positive effect on taxpayer compliance. Service quality has positive effect on taxpayer compliance. Taxation socialization has positive effect on taxpayer compliance. Knowledge of taxpayer taxation has positive effect on taxpayer compliance. This research is expected to be a motivation for the samsat office to be able to improve physical and non-physical facilities to improve taxpayer compliance.

Keywords: progressive tariffs, service quality, tax socialization, taxpayer knowledge, compliance.
\end{abstract}

\section{PENDAHULUAN}

Pajak merupakan sumber terbesar penerimaan suatu Negara, khususnya Indonesia

yang tidak lain sebagai sumber utama pembiayaan dan pembangunan nasional 
Luh Putu Cintya Wijayanti dan I Made Sukartha. Pengaruh...

untuk meningkatkan kesejahteraan masyarakat. Banyak negara di masa krisis global menjadikan pajak sebagai instrumen ekonomi yang memberikan kehidupan bagi berlangsungnya pembangunan yang berkesinambungan. Pajak Kendaraan Bermotor adalah pajak atas kepemilikan dan/atau penguasaan kendaraan bermotor.Dalam penerimaan PKB tentulah mempunyai kendala tertentu seperti terjadinya perlambatan pertumbuhan ekonomi Nasional yang berdampak pada menurunnya kemampuan daya beli masyarakat, sehingga berpengaruh pada tertundanya pembayaran pajak kendaraan bermotor. Tertundanya pembayaran pajak kendaraan bermotor yang menimbulkan utang pajak dan sanksi pajak pada wajib pajak kendaraan bermotor. Menurut Ali et al (2001) sanksi perpajakan dan audit adalah suatu kebijakan yang efektif untuk mencegah ketidakpatuhan wajib pajak.

Meningkatnya jumlah kendaraan bermotor dengan pesat setiap tahunnya terus disebabkan oleh populasi yang semakin bertambah, transportasi yang sudah menjadi kebutuhan primer masyarakat, ditambah lagi gayahidup yang selalu mengemukakan gengsi. Menurut Yadnyana dan Sudiksa yang dikutip oleh Susilawati (2013) kepatuhan pajak adalah suatu sikap pada fungsi pajak, berupa konstelasi dari komponen kognitif, efektif, dan konatif yang berinteraksi dalam memahami, merasakan dan berperilaku pada makna dan fungsi pajak.

Faktor yang memengaruhi penerimaan pajak suatu negara diantaranya adalah tingkat kepatuhan Wajib Pajaknya (Chau, 2009). Kepatuhan dalam perpajakan merupakan suatu kedisiplinan yang dimiliki oleh wajib pajak untuk melaksanakan kewajibannya dibidang perpajakan sesuai dengan undang-undang 
yang berlaku. Marti et al. (2010) menjelaskan bahwa kesadaran dan kepatuhan masyarakat pada peraturan perpajakan tentunya berpengaruh pada peningkatan penerimaan pajak negara. Kepatuhan pajak merupakan salah satu penunjang yang bisa mampu meningkatkan Pendapatan Asli Daerah.Menurut Fuadi (2013), penerimaan pendapatan pajak agar dapat berlangsung secara maksimal tentunya membutuhkan kesadaran masyarakat untuk mematuhi kewajiban perpajakan yang berlaku. Menurut Heenkenda, et al. (2016), ketidakpatuhan membayar pajak dianggap sebagai tantangan serius, yang dapat melemahkan administrasi perpajakan dan kinerja penerimaan pajak. Persoalan mengenai kepatuhan wajib pajak telah menjadi persoalan yang penting diIndonesia karena apabila Wajib Pajak tidak patuh maka dapat menimbulkan keinginan untuk melakukan tindakan penghindaran, pengelakan dan pelalaian pajak yang pada akhirnya akan merugikan Negara yaitu berkurangnya penerimaan pajak.

Ketidakpatuhan dalam membayar pajak kendaraan bermotor tentu saja menjadi permasalahan setiap tahunnya di Bali, terutama di Kabupaten Bangli.Peneliti memilih Kabupaten Bangli sebagai lokasi penelitian karena pada saat saya melakukan penelitian ini, belum ada yang melakukan penelitian di Kabupaten Bangli sebelumnya. Dalam Tabel 1 menggambarkan permasalahan yang terjadi setiap tahunnya di Kabupaten Bangli mengenai Kepatuhan Wajib Pajak Kendaraan Bermotor. 
Tabel 1.

Perbandingan antara Target Unit dan Realisasi Unit Wajib Pajak yang telah melaksanakan Kewajibannya di Kantor SAMSAT Kabupaten Bangli

$\begin{array}{llll}\text { Jenis Kendaraan } & 2015 & 2016 & 2017\end{array}$

\begin{tabular}{lcccccc}
\hline Sedan & Target & Realisasi & Target & Realisasi & Target & Realisasi \\
& 38 & 139 & 37 & 151 & 177 & 150 \\
Jeep & 225 & 409 & 242 & 482 & 522 & 501 \\
Minibus & 1.826 & 3.477 & 1.918 & 4.109 & 4.438 & 4.658 \\
Microbus & 2 & 13 & 2 & 16 & 17 & 20 \\
Bus & 13 & 14 & 12 & 4 & 18 & 1 \\
Pick Up & 7.383 & 3.876 & 7.835 & 3.926 & 4.948 & 4.126 \\
Light Truck & 3.586 & 1.193 & 3.901 & 1.131 & 1.523 & 1.185 \\
Truck & 98 & 47 & 124 & 42 & 60 & 50 \\
Sepeda Motor & 57.189 & 47.425 & 62.057 & 47.339 & 60.538 & 47.596 \\
Jumlah & 70.360 & 56.593 & 76.128 & 57.200 & 72.241 & 58.287 \\
\% perbandingan & \multicolumn{2}{c}{$80.43 \%$} & \multicolumn{2}{c}{$75.14 \%$} & & \multicolumn{2}{c}{$80.68 \%$} \\
\hline
\end{tabular}

Sumber : Kantor SAMSAT Bangli 2018

Berdasarkan data pada Tabel 1, dapat kita lihat bahwa realisasi unit WP yang telah melaksanakan kewajibannya tidak pernah mencapai target secara keseluruhan. Berdasarkan data yang diperoleh dari tahun 2015 persentase perbandingan target dan realisasi unit PKB sebanyak 80,43\%, tahun 2016 sebanyak 75,14\% sedangkan ditahun 2017 sebanyak 80,86\%. Hal ini menunjukan adanya kesenjangan antara target unit dan realisasi unit kepatuhan wajib pajak dalam menjalankan kewajibannya. Ini mengindikasikan bahwa tingkat kepatuhan wajib pajak di Kabupaten Bangli masih rendah. Oleh karenaitukepatuhan Wajib Pajak untuk PKB di Kabupaten Bangli perlu di teliti untuk mengetahui apa yang menjadi permasalahannya serta faktor-faktor apa saja yang mempengaruhi kepatuhan Wajib Pajaknya. 
Kepatuhan wajib pajak dipengaruhi oleh berbagai faktor, salah satunya adalah pajak progresif. Alasan peneliti memilih variable ini karena pajak progresif merupakan peraturan baru yang diterapkan sejak 2014 lalu. Pajak progresf di bebankan kepada wajib pajak sepenuhnya, maka peneliti menganggap bahwa pajak progresif mampu mempengaruhi tingkat kepatuhan wajib pajak. Hal ini sekaligus dapat menumbuhkan perasaan adil bagi seluruh wajib pajak. Tarif progesif ini di kenakan kepada kendaraan bermotor berdasarkan atas nama dan/alamat yang sama sesuai kartu keluarga. Respons Wajib Pajak pada penetapan pajak khususnya tarif pajak progresif, tentu dapat mempengaruhi kepatuhan dari WP dalam membayar pajak. Obyek pajak kena pajak progresif adalah kendaraan bermotor pelat hitam atau pribadi dengan penggunaan untuk konsumtif, seperti sedan, jeep, minibus, pick up, station wagon, kabin ganda.

Selain diterapkannya tarif progresif, kualitas pelayanan juga menjadi faktor yang dapat mempengaruhi kepatuhan Wajib Pajak. Hal ini sesuai dengan yang dikemukakan Danuta (1997) bahwa meningkatkan kepatuhan wajib pajak dapat dilakukan melalui peningkatan kualitas pelayanan. Pusat pelayanan Pajak Kendaraan Bermotor Kabupaten Bangli terletak di KantorSAMSAT Bangli, di instansi inilah para wajib pajak kendaraan bermotor membayar pajak kendaraan bermotornya. Oleh karena itu sudah seharusnya Kantor bersama SAMSAT Bangli dapat memberikan pelayanan publik yang baik agar dapat meningkatkan kepatuhan wajib pajak. Menurut peneliti setiap wajib pajak pasti menginginkan pelayanan yang ramah dan informatif, termasuk peneliti sendiri. Berdasarkan hal 
Luh Putu Cintya Wijayanti dan I Made Sukartha. Pengaruh...

tersebut, peneliti tertarik untuk mengetahui pengaruh kualitas pelayanan pada kepatuhan wajib pajak dalam menalankan kewajibannya.

Mengingat begitu pentingnya membayar pajak dan dengan adanya berbagai informasi terbaru mengenai perpajakan, diharapkan Sosialisasi Perpajakan yang baik dapat meningkatkan kepatuhan wajib pajak.Pentingnya sosialisasi memberikan pengertian kepada masyarakat dalam membayar pajak, dengan adanya sosialisasi perpajakan masyarakat menjadi mengerti dan paham mengenai manfaat membayar pajak (Winerungan,2013). Kurangnya informasi yang diterima masyarakat karena rendahnya sosialisasi perpajakan dapat menyebabkan mereka tidak memahami bagaimana caranya melaksanakan kewajiban perpajakan dan pada akhirnya tidak melaksanakan kewajibannya, dan hal tersebut berdampak pada penerimaan pajak negara (Harryanto dan Toly,2013). Apabila pemerintah berhasil dalam menjalankan sosialisasi perpajakan, maka masyarakat lebih memahami perpajakan dan kepatuhan wajib pajak juga bisa ditingkatkan.Dalam Hasil penelitian yang dilakukan oleh Dharma (2014), menyimpulkan bahwa sosialisasi perpajakan berpengaruh signifikan pada Kepatuhan Wajib Pajak PKB dan BBNKB.

Pengetahuan perpajakan merupakan pemahaman dasar bagi wajib pajak mengenai hukum, undang-undang, dan tatacara perpajakan yang benar. Wajib pajak akan melakukan dan melaksanakan kewajiban maupun hak perpajakannya apabila mereka memiliki pengetahuan yang cukup dan baik mengenai pentingnya pajak serta memahami kewajiban sebagai seorang wajib pajak. Dalam meningkatkan kepatuhan wajib pajak diperlukan juga pengetahuan perpajakan 
oleh wajib pajak itu sendiri. Hasil penelitian sebelumnya menunjukkan bahwa pengetahuan wajib pajak juga dapat menjadi faktor penting yang mempengaruhi meningkatkan kepatuhan Wajib Pajak (Richardson, 2006).Pengetahuan merupakan hal yang penting dalam membantu wajib pajak dalam melakukan kewajibannya, khususnya pengetahuan di bidang perpajakan (Noormala, 2008). Salah satu alat yang efektif untuk mendorong kepatuhan wajib pajak adalah pendidikan pajak yang dapat menambah pengetahuan tentang perpajakan, hal ini dikemukakan oleh Taman \& Hyun (2003) dalam Marziana et al 2009). Sedangkan menurut Carolina, 2009 (dalam Khasanah, 2014:22) pengetahuan pajak adalah informasi pajak yang dapat digunakan wnajib pajak sebagai dasar untuk bertindak, mengambil keputusan, dan untuk menempuh arah atau strategi tertentu sehubungan dengan pelaksanaan hak dan kewajibannya dibidang perpajakan.

Tujuan penelitian adalah untuk untuk memberikan bukti empiris pengaruh diterapkannya tarif progresif pada kepatuhan wajib pajak kendaraan bermotor di Kabupaten Bangli, pengaruh kualitas pelayanan pada kepatuhan wajib pajak kendaraan bermotor di Kabupaten Bangli, pengaruh sosialisasi perpajakan pada kepatuhan wajib pajak kendaraan bermotor di Kabupaten Bangli, dan pengaruh pengetahuan perpajakan wajib pajak pada kepatuhan wajib pajak kendaraan bermotor di Kabupaten Bangli.Hasil penelitian ini diharapkan dapat memberikan bukti empiris yang mendukung teori atribusibahwa kepatuhan wajib pajak dalam membayar Pajak Kendaraan Bermotor dapat dipengaruhi oleh faktor internal dan faktor eksternal wajib pajak, antara tarif progresif, kualitas pelayanan, sosialisasi perpajakan dan pengetahuan perpajakan wajib pajak serta mendukung Theory of 
Planned Behavior yang digunakan dalam penelitian ini. Selain itu,penelitian ini diharapkan dapat menjadi daftar rujukan bagi peneliti lainnya yang ingin melakukan penelitian dengan objek yang sama.Hasil Penelitian ini diharapkan dapat memecahkan masalah - masalah yang terjadi pada kepatuhan wajib pajak kendaraan bermotor di Kabupaten Bangli. Dan diharapkan dapat memberikan informasi, bahan rujukan dan evaluasi bagi Pemerintah Provinsi Bali khususnya kantor SAMSAT Bangli.

Berdasarkan landasan teori dan kajian empiris penelitian sebelumnya, maka peneliti merumuskan kerangka desain penelitian seperti pada Gambar 1. sebagai berikut.

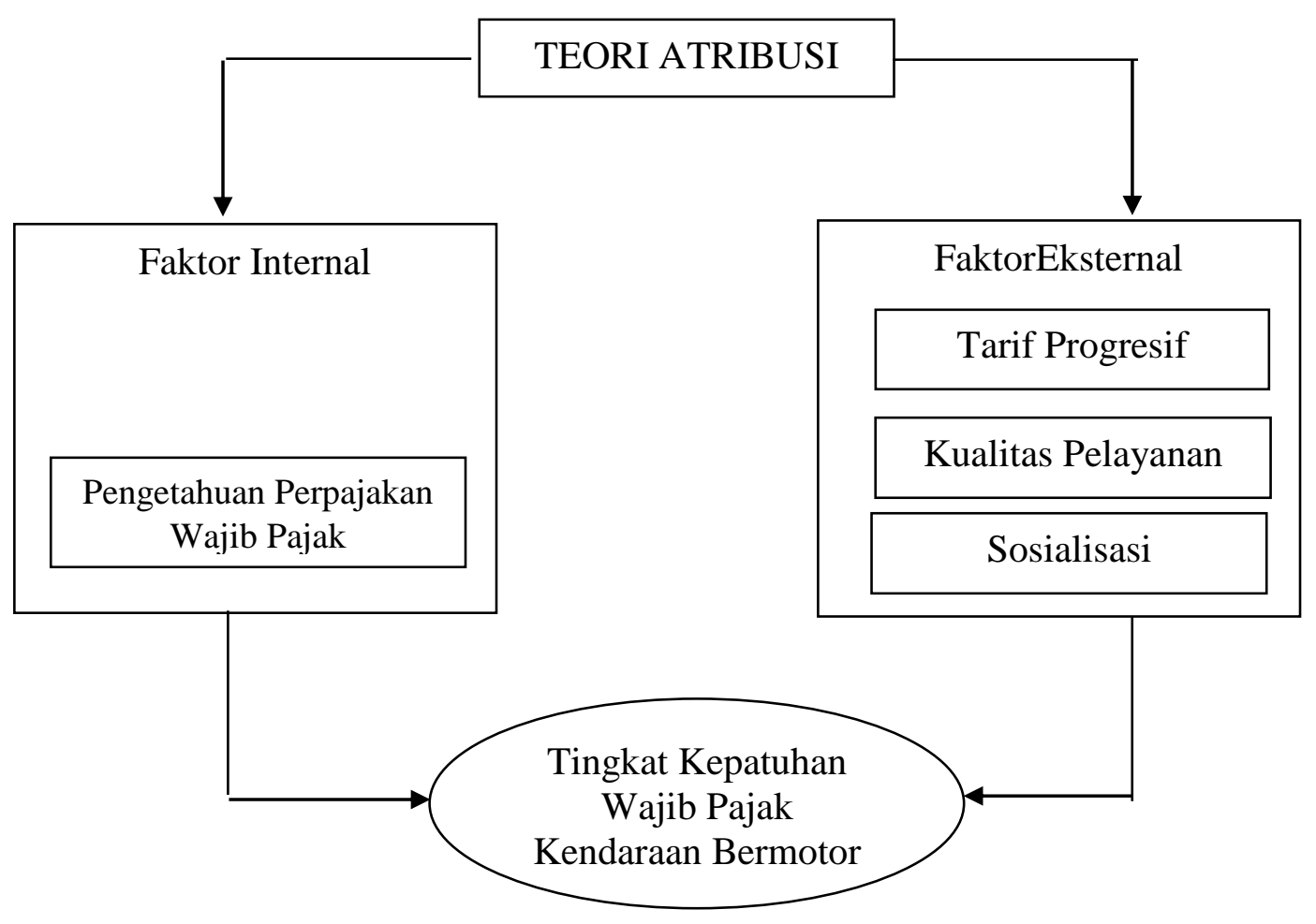

Gambar 1. Kerangka Desain Penelitian 
Berdasarkan teori atribusi, tarif progresif merupakan penyebab internal yang dapat mempengaruhi kepatuhan wajib pajak.Dengan meningkatnya kepatuhan faktor eksternal maka akan meningkatkan faktor internalnya. Tarif progresif ditetapkan oleh Pemerintah untuk ditetapkan kepada Wajib Pajak berdasarkan Objek Pajaknya. Penerapan Tarif Progresif diterapkan dengan tujuan untuk mengurangi kemacetan dan menekan jumlah kendaraan bermotor di Provinsi Bali, khususnya di Kabupaten Bangli. Dengan adanya tarif progresif maka semakin banyak WP memiliki kendaraan, semakin besar juga pajak yang harus dibayarkannya.

Sesuai dengan penelitian Chau (2009), bahwa beban pajak progresif berpengaruh positif dan signifikan pada kepatuhan,ditunjukkan dengan koefisien 0,296 dan diterima karena $\mathrm{t}$ statistik 2,506 lebih besar dari t tabel 1,96. Hasil estimasi tersebut berarti semakin meningkat beban pajak progresif maka semakin patuh WP dalam membayar pajak progresif. Wisnu dan Made Kembar (2015) mengemukakan hasil penelitiannya yang menemukan hasil bahwa Tarif Progresif mempengaruhi kepatuhan wajib pajak dalam membayar pajak di Kota Denpasar. Hal serupa juga diungkapkan oleh Ananda(2015) dan Prawegis (2016) yang menyimpulkan bahwa tarif perpajakan berpengaruh terhadap kepatuhan wajib pajak UMKM.Berdasarkan pernyataan-pernyataan dan hasil dari penelitian sebelumnya maka hipotesis yang diajukan dalam penelitian ini adalah sebagai berikut:

$\mathrm{H}_{1}$ : Tarif Progresif berpengaruh positif pada kepatuhan wajib pajak kendaraan bermotor di Kabupaten Bangli. 
Berdasarkan teori atribusi, kualitas pelayanan merupakan faktor eksternal yang mempengaruhi kepatuhan wajib pajak. Kualitas pelayanan dinilai sebagai berbandingan antara harapan yang diinginkan oleh pelanggan dengan penilaian mereka pada kinerja aktual dari suatu penyediaan layanan (Cronin dan Steveb, 1992). Kepuasan wajib pajak sebagai pelanggan dapat ditingkatkan melalui peningkatan kualitas dan kuantitas pelayanan. Hal ini diharapkan dapat meningkatkan kepatuhan wajib pajak dalam bidang perpajakan (Supadmi, 2009).

Amanda (2013) membuktikan bahwa kualitas pelayanan berpengaruh positif terhadap kepatuhan wajib pajak dalam membayar Pajak Kendaraan Bermotor di Kantor Bersama SAMSAT Denpasar.Hal ini serupa dengan hasil yang ditemui oleh Lisa dan Supadmi (2017) bahwa kualitas pelayanan berpengaruh positif dan signifikan pada kepatuhan wajib pajak dalam membayar pajak kendaraan bermotor di Kantor Bersama SAMSAT Tabanan.Berdasarkan pernyataanpernyataan dan hasil dari penelitian sebelumnya maka hipotesis yang diajukan dalam penelitian ini adalah sebagai berikut:

$\mathrm{H}_{2}$ : Kualitas pelayanan berpengaruh positif pada kepatuhan wajib pajak kendaraan bermotor di Kabupaten Bangli.

Berdasarkan teori atibusi, sosialisasi perpajakan merupakan faktor ekternal yan mempengaruhi kepatuhan wajib pajak. Sosialisasi perpajakan dari aparat pajak sangat diharapkan oleh wajib pajak. Winerungan (2013) menyatakan bahwa kurangnya sosialisasi mungkin berdampak pada rendahnya pengetahuan masyarakat tentang pajak yang menyebabkan rendahnya kesadaran masyarakat untuk melaporkan dan membayar pajak yang pada akhirnya mungkin menyebabkan rendahnya tingkat kepatuhan wajib pajak. 
Widnyani (2016) dan Dharma (2014) menyatakan bahwa sosialisasi perpajakan berpengaruh positif dan signifikan terhadap kepatuhan wajib pajak. Wajib pajak yang mendapatkan sosialisasi perpajakan yang baik maka cenderung untuk patuh dalam melaksanakan kewajiban perpajakannya. Hal ini serupa dengan hasil yang ditemukan Lisa dan Supadmi (2017) serta Meggy dan Putu Ery (2017) bahwa sosialisasi perpajakan berpengaruh positif dan signifikan terhadap kepatuhan wajib pajak.Berdasarkan pernyataan-pernyataan dan hasil dari penelitian sebelumnya maka hipotesis yang diajukan dalam penelitian ini adalah sebagai berikut:

$\mathrm{H}_{3}$ : Sosialisasi perpajakan berpengaruh positif pada kepatuhan wajib pajak kendaraan bermotor di Kabupaten Bangli.

Dalam penelitian yang telah dilakukan oleh Nova Kristanty, Siti Khairani dan Icha Fajriana(2014) menemukan hasil bahwa terdapat pengaruh yang signifikan antara pengetahuan Wajib Pajak terhadap tingkat kepatuhan Wajib Pajak Badan di Kantor Pelayanan Pajak Madya Palembang secara parsial. Hasil ini serupa dengan yang ditemukan oleh Lisa dan Supadmi (2017) yang menyatakan bahwa pengetahuan berpengaruh pada kepatuhan wajib pajak kendaraan bermotor.

Fjeldstad et al. (2012) menyatakan bahwa kepatuhan wajib pajak dapat diukur melalui pengetahuan yang dimiliki sehingga tidak dapat menghindari kewajiban perpajakannya dan timbul kesadaran untuk patuh dalam membayar pajak. Pada penelitian yang dilakukan oleh Siregar (2012) menyatakan pengetahuan perpajakan berpengaruh positif terhadap kepatuhan wajib pajak. Hal ini serupa dengan hasil dari penelitian yang dilakukan oleh Supriyati dan Nur 
Luh Putu Cintya Wijayanti dan I Made Sukartha. Pengaruh...

Hidayati (2008:45-50) dikatakan bahwa variabel pengetahuan wajib pajak memiliki pengaruh yang positif terhadap variabel kepatuhan wajib pajak dalam membayar pajaknya.Berdasarkan pernyataan-pernyataan dan hasil dari penelitian sebelumnya maka hipotesis yang diajukan dalam penelitian ini adalah sebagai berikut:

$\mathrm{H}_{4}$ : Pengetahuan Wajib Pajak berpengaruh positif pada kepatuhan wajib pajak kendaraan bermotor di Kabupaten Bangli.

\section{METODE PENELITIAN}

Penelitian ini dilakukan di Kantor Sistem Administrasi Manunggal Satu Atap (SAMSAT) Kabupaten Bangli.Objek penelitian adalah suatu sifat dari objek yang ditetapkan oleh peneliti untuk dipelajari dan kemudian memeroleh kesimpulan (Sugiyono, 2014).Objek dari penelitian ini adalah tarif progresif, kualitas pelayanan, sosialisasi perpajakan, pengetahuan perpajakan wajib pajak dan kepatuhan wajib pajak kendaraan bermotor di Kantor SAMSAT Bangli.

Tarif progresif merupakan pajak yang sistem pemungutannya dengan menaikkan persentase tarif pajak yang harus dibayar sesuai dengan kenaikan objek pajak. Indikator yang digunakan untuk mengukur tarif pajak progresif adalah: 1). Jumlah kepemilikan kendaraan, merupakan banyaknya kendaraan yang dimiliki oleh satu nama wajib pajak; 2). Peningkatan Tarif, tarif yang dikenakan kepada wajib pajak sesuai dengan jumlah kendaraannya, untuk roda dua dan roda tiga dibawah $250 \mathrm{cc}$, kepemilikan pertama sebesar 1,5\%, kedua $2 \%$, ketiga 2,5\%, keempat $3 \%$, kelima dan seterusnya $3,5 \%$. Untuk kendaraan roda dua dan roda tiga diatas $250 \mathrm{cc}$ dan roda empat, kepemilikan pertama sebesar $1,75 \%$, kedua $3 \%$, ketiga 4,5\%, keempat 5\%, kelima, seterusnya 7,5\%; 3). Besaran Pajak, jumlah 
yang wajib dibayarkan oleh wajib pajak sesuai dengan nilai jual kendaraan; 4). Kemampuan membayar, yang artinya semakin tinggi penghasilan seseorang maka memiliki kemampuan membayar yang lebih besar.

Kualitas pelayanan merupakan perbandingan antara harapan dan penilaian mereka terhadap kinerja aktual dari suatu penyedia layanan. Pelayanan yang berkualitas adalah pelayanan yang mampumemberikan kepuasan kepada pelanggan dan tetap dalam batas memenuhi standar pelayanan yang dapat dipertangung-jawabkan serta harus dilakukan secara terus-menerus (Supadmi, 2009). Untuk mengukur kualitas pelayanan dalam kaitannya dengan kepatuhan WP dalam membayar Pajak Kendaraan Bermotor digunakan indikator sebagai berikut: 1). Bukti langsung, meliputi fasilitas fisik, pegawai, perlengkapan dan komunikasi; 2). Keandalan, merupakan kemampuan para petugas pajak memberikan pelayanan yang memuaskan pada pelanggan; 3). Daya tanggap, merupakan karakteristik kecocokan dalam pelayanan manusia yaitu keinginan petugas pajak untuk membantu wajib oajak dalam memberikan pelayanan dengan tanggap; 4). Jaminan, yaitu mencakup kemampuan, kesopanan dan sifat dapat dipercaya yang dimiliki oleh petugas pajak bebas dari risiko, bahaya atau keraguraguan; 5). Empati, yaitu meliputu kemudahan petugas dalam melakukan hubungan komunikasi yang baik dan memahami para wajib pajak.

Sosialisasi merupakan upaya untuk memberikan pengertian, informasi, dan pembinaan kepada masyarakat mengenai segala sesuatu yang berhubungan dengan perpajakan dan perundang-undangan. Untuk mengukur sosialisasi perpajakan dalam kaitannya dengan kepatuhan wajib pajak dalam membayar 
Luh Putu Cintya Wijayanti dan I Made Sukartha. Pengaruh...

pajak kendaraan bermotor digunakan tiga indikator (Yogatama, 2014), yaitu : 1). Tata Cara Sosialisasi, yang artinya sosialisasi dilakukan sesuai dengan peraturan pajak yang berlaku; 2). Frekuensi Sosialisasi, yang artinya sosialisasi dilakukan secara teratur karena peraturan dan tatacara pembayaran pajak biasanya mengalami perubahan; 3). Kejelasan Sosialisasi, yang artinya sosialisasi yang dilakukan dapat menyampaikan semua informasi secara jelas dan benar kepada wajib pajak.

Pengetahuan Perpajakan Wajib Pajak adalah informasi pajak yang dapat digunakan wajib pajak sebagai dasar untuk bertindak, mengambil keputusan, serta menempuh arah ataupun strategi tertentu yang berhubungan dengan pelaksanaan hak dan kewajibannya dibidang perpajakan (Veronica Carolina, 2009). Indikator untuk mengukur pengetahuan pajak dalam kaitannya dengan kepatuhan wajib pajak dalam membayar pajak kendaraan bermotor menggunakan instrumen pernyataan penelitian yang dilakukan oleh Supriyati dan Nur Hidayati (2008), yaitu: 1). Pengetahuan mengenai batas waktu pembayaran dan pelaporan; 2). Pengetahuan mengenai ketentuan umum dan tatacara perpajakan; 3). Pengetahuan mengenai sistem perpajakan.

Kepatuhan dalam perpajakan berarti taat, tunduk dan patuh serta melaksanakan ketentuan perpajakan Siti Kurnia Rahayu (2010:139). Indikator kepatuhan wajib pajak dalam membayar Pajak Kendaraan Bermotor menurut Erly Suandy (2014) adalahsebagai berikut: 1). Patuh terhadap kewajiban intern; 2). Patuh terhadap kewajiban tahunan; 3). Patuh terhadap ketentuan material dan yudiris formal perpajakan. 
Populasi dalam penelitian ini adalah sejumlah 58.287 seluruh Wajib Pajak Kendaraan Bermotor yang membayar pajak kendaraannya di Kantor SAMSAT Bangli per 31 Desember 2017.Adapun yang menjadi kriteria responden dalam penelitian ini adalah responden yang merupakan Wajib pajak pemilik kendaraan bermotor yang membayar pajak kendaraannya di Kantor SAMSAT Bangli per 31 Desember 2017.

Penelitian ini dilakukan uji asumsi klasik terlebih dahulu kemudian dilakukan teknik analisis data. Teknik analisis data dalam penelitian ini menggunakan uji Analisis Regresi Linear Berganda. Penelitian ini menggunakan analisis regresi linear berganda, karena terdiri dari satu variabel dependen dan beberapa variabel independen. Model regresi linear berganda ditunjukkan oleh persamaan regresi berikut.

$$
Y=\alpha+\beta_{1} X_{1}+\beta_{2} X_{2}+\beta_{3} X_{3}+\beta_{4} X_{4}+\varepsilon
$$

Keterangan:

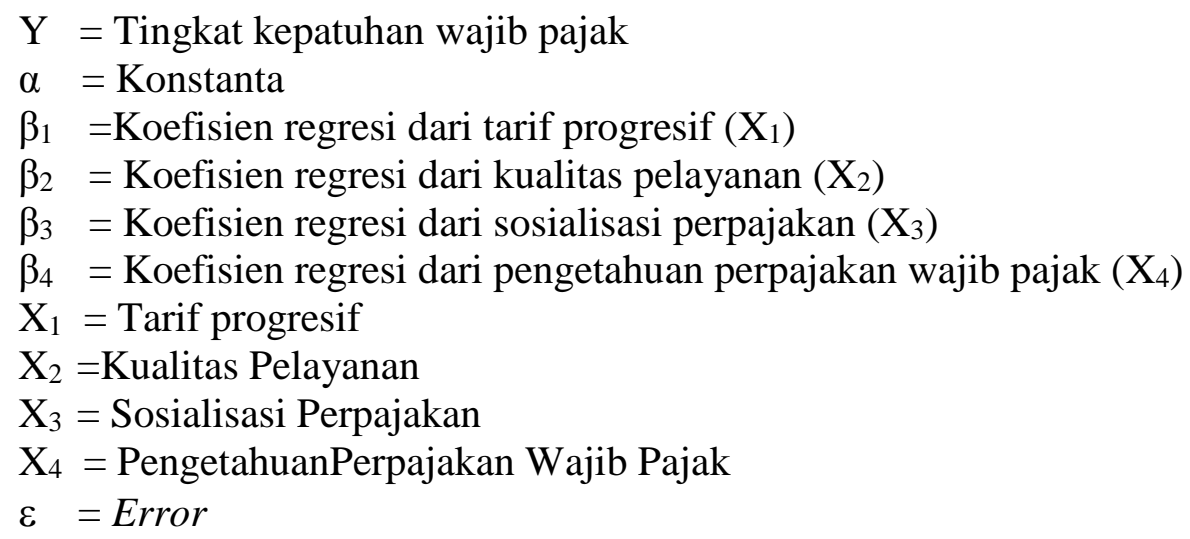

\section{HASIL DAN PEMBAHASAN}

Kantor SAMSAT Bangli merupakan pusat pembayaran Pajak Kendaraan Bermotor di Kabupaten Bangli yang beralamat di Kawan Sub-distric Kabupaten 
Luh Putu Cintya Wijayanti dan I Made Sukartha. Pengaruh...

Bangli. Kantor SAMSAT Bangli memiliki lokasi yang cukup strategis dengan segala fasilitas yang memadai.Jumlah responden terbanyak berdasarkan jenis kelamin adalah responden berjenis kelamin laki-laki yakni sebanyak 269 orang sedangkan jumlah responden perempuan sebanyak 128 orang dari total responden 397 orang responden.

Dilihat dari rentang umur, jumlah responden terbanyak berada pada rentang usia 44-52 tahun yakni sebanyak 138 orang, disusul dengan rentang usia 35-43 tahun sebanyak 102 orang, usia 26-34 tahun sebanyak 67 orang, responden dengan usia lebih dari 53 tahun sebanyak 62 responden, sedangkan yang memiliki jumlah terkecil adalah responden rentang usia 17-25 tahun dengan jumlah 28 orang. Apabila dilihat dari tingkat pendidikan terakhir, dapat dijelaskan bahwa responden dengan tingkat pendidikan terakhir yakni SMA dengan jumlah responden sebanyak 258 orang, disusul dengan responden dengan tingkat pendidkan terakhir Diploma sebanyak 62 orang, responden dengan pendidikan terakhir S1 sebanyak 39 orang, SMP sebanyak 22, SD sebanyak 14 orang dan tidak ada responden dengan tingkat pendidikan terakhir S2 dan S3.

Sebelum dilakukan uji regresi linear berganda, dilakukan uji instrumen terlebih dahulu. Instrumen yang valid berarti instrumen yang dapat digunakan untuk mengukur apa yang seharusnya diukur. Hasil uji validitas instrumen penelitian menunjukkan bahwa seluruh indikator memiliki nilai Pearson Correlation yang lebih besar dari angka 0,30 sehingga seluruh indikator tersebut dikatakan telah memenuhi syarat validitas data. 
Insturumen yang reliable adalah suatu instrument yang bila digunakan beberapa kali untuk mengukur objek yang sama, maka akan menghasilkan data yang sama. Instrument dikatakan reliable untuk mengukur variabel bila memiliki nilai Cronbach Alpha > 0,60. Hasil uji reliabilitas instrumen pada penelitian ini menunjukkan bahwa kelima instrumen penelitian memiliki koefisien cronbach's alpha yang lebih besar dari angka 0,60 sehingga pernyataan pada kuesioner dapat dikatakan reliabel.

Statistik deskriptif digunakan untuk memberikan informasi mengenai karakteristik variabel-variabel penelitian, yaitu jumlah sampel, nilai rata-rata (Mean), nilai minimum dan maksimum, serta standar deviasi pada variabelvariabel yang diteliti. Hasil Statistik deskriptif dapat dilihat pada Tabel 4 sebagai berikut.

Tabel 2.

Hasil Statistik Deskriptif

\begin{tabular}{|c|c|c|c|c|c|c|c|c|}
\hline & \multirow[t]{2}{*}{$\mathbf{N}$} & \multirow[t]{2}{*}{$\begin{array}{l}\text { Rang } \\
\text { e }\end{array}$} & \multirow[t]{2}{*}{$\begin{array}{l}\text { Minimu } \\
\text { m }\end{array}$} & \multirow[t]{2}{*}{ Maximum } & \multirow[t]{2}{*}{ Mean } & \multirow[b]{2}{*}{$\begin{array}{l}\text { Std. } \\
\text { Erro } \\
\text { r }\end{array}$} & \multirow{2}{*}{$\begin{array}{c}\text { Std. } \\
\text { Deviatio } \\
\mathbf{n} \\
\text { Statistic }\end{array}$} & \multirow{2}{*}{$\begin{array}{c}\text { Variance } \\
\text { Statistic }\end{array}$} \\
\hline & & & & & & & & \\
\hline $\mathrm{X} 1$ & 397 & 21 & 19 & 40 & 32.64 & .184 & 3.666 & 13.439 \\
\hline $\mathrm{X} 2$ & 397 & 47 & 43 & 90 & 74.60 & .323 & 6.438 & 41.452 \\
\hline X3 & 397 & 19 & 16 & 35 & 28.76 & .151 & 3.010 & 9.060 \\
\hline $\mathrm{X} 4$ & 397 & 12 & 13 & 25 & 21.12 & .108 & 2.159 & 4.662 \\
\hline $\mathrm{Y}$ & 397 & 14 & 21 & 35 & 29.07 & .128 & 2.542 & 6.460 \\
\hline $\mathrm{N}$ & 397 & & & & & & & \\
\hline
\end{tabular}

Sumber: Data diolah, 2018

Variabel tarif progresif memiliki nilai minimum sebesar 19,00 dan nilai maksimum sebesar 40,00. Nilai rata-rata untuk variabel tarif progresif adalah sebesar 32,64 dengan penyimpangan sebesar 3,666. Variabel kualitas pelayanan memiliki nilai minimum sebesar 43,00 dan nilai maksimum sebesar 90,00. Nilai 
Luh Putu Cintya Wijayanti dan I Made Sukartha. Pengaruh...

rata-rata untuk variabel kualitas pelayanan adalah sebesar 74,60 dengan penyimpangan sebesar 6,438 .Variabel kualitas pelayanan memiliki nilai minimum sebesar 16,00 dan nilai maksimum sebesar 35,00. Nilai rata-rata untuk variabel sosialisasi perpajakan adalah sebesar 28,76 dengan penyimpangan sebesar 3,010.Variabel pengetahuan perpajakan memiliki nilai minimum sebesar 13,00 dan nilai maksimum sebesar 25,00. Nilai rata-rata untuk variable pengetahuan perpajakan adalah sebesar 2,112 dengan penyimpangan sebesar 2,159.Variabel kepatuhan wajib pajak memiliki nilai minimum sebesar 21,00 dan nilai maksimum sebesar 35,00. Nilai rata-rata untuk variabel kepatuhan wajib pajak adalah sebesar 29,07 dengan penyimpangan sebesar 2,642.

Selanjutnya dilakukan uji asumsi klasik, model persamaan regresi berdistribusi normal karena memiliki nilai Kolmogorov Smirnov sebesar 0,107 lebih besar dari 0,05. Nilai signifikansi masing-masing variabel lebih besar dari 0,05 sehingga dapat disimpulkan bahwa model regresi bebas dari gejala heteroskedastisitas.Nilai tolerance dan VIF dari seluruh variabel tersebut menunjukkan bahwa nilai tolerance untuk setiap variabel lebih besar dari $10 \%$ dan nilai VIF lebih kecil dari 10 yang berarti model persamaan regresi bebas dari multikolinearitas.

Setelah semua asumsi klasik terpenuhi, maka selanjutnya memaparkan hasil analisis regresi linier berganda. Analisis ini digunakan untuk mengetahui seberapa besar tarif progresif $\left(\mathrm{X}_{1}\right)$, kualitas pelayanan $\left(\mathrm{X}_{2}\right)$, sosialisasi perpajakan $\left(\mathrm{X}_{3}\right)$ dan pengetahuan perpajakan wajib pajak $\left(\mathrm{X}_{4}\right)$ pada kepatuhan wajib pajak 
dalam membayar pajak kendaraan bermotor (Y) di Kantor SAMSAT Bangli..Hasil pengujian disajikan pada Tabel 3 berikut ini.

Tabel 3.

Hasil Analisis Regresi Linier Berganda

\begin{tabular}{ccccc}
\hline Variabel & $\begin{array}{c}\text { Unstandardized } \\
\text { Beta }\end{array}$ & $\begin{array}{c}\text { Std. } \\
\text { Error }\end{array}$ & T hitung & $\begin{array}{c}\text { Sig. } \\
\text { uji t }\end{array}$ \\
\hline (Constant) & 10,213 & 1,307 & 7,815 & 0,000 \\
Tarif Progresif $\left(\mathrm{X}_{1}\right)$ & 0,110 & 0,091 & 3,084 & 0,002 \\
Kualitas Pelayanan $\left(\mathrm{X}_{2}\right)$ & 0,086 & 0,069 & 3,531 & 0,000 \\
Sosialisasi Perpajakan $\left(\mathrm{X}_{3}\right)$ & 0,146 & 0,045 & 3,007 & 0,003 \\
Pengetahuan Perpajakan Wajib & 0,222 & 0,079 & 3.501 & 0,001 \\
Pajak $\left(\mathrm{X}_{4}\right)$ & & & &
\end{tabular}

Sumber: Data diolah, 2018

Berdasarkan hasil analisis regresi linier berganda seperti yang disajikan pada Tabel 5, maka dapat dibuat persamaan regresi sebagai berikut:

$$
Y=10,213+0,110 X_{1}+0,086 X_{2}+0,146 X_{3}+0,222 X_{4}
$$

Nilai signifikan uji F yaitu sebesar 0,000 lebih kecil dari 5 persen $(0,000<$ 0,05). Hal ini berarti variabel bebas berpengaruh serempak pada variabel terikat pada tingkat signifikan 5 persen. Nilai dari Adjusted R Square adalah 0,346 atau $34,6 \%$, ini artinya sebesar 34,6 persen variansi kepatuhan wajib pajak kendaraan bermotor dipengaruhi oleh variansitarif progresif, kualitas pelayanan, sosialisasi perpajakan dan pengetahuan perpajakan wajib pajak. Sedangkan sisanya sebesar 65,4 persen dijelaskan oleh variable-variabel lain yang tidak dijelaskan dalam penelitian ini.

Hipotesis pertama penelitian ini menyatakan bahwa tarif progresif berpengaruh positif pada kepatuhan wajib pajak kendaraan bermotor di Kabupaten Bangli. Hasil pengujian dengan menggunakan regresi linier berganda sejalan dengan hipotesis yang dirumuskan, menunjukkan bahwa tarif progresif berpengaruh positif pada kepatuhan wajib pajak kendaraan bermotor di Kabupaten 
Luh Putu Cintya Wijayanti dan I Made Sukartha. Pengaruh...

Bangli. Nilai regresi menunjukkan nilai koefisien positif sebesar 0,110 dengan nilai signifikansi sebesar 0,002 yang lebih kecil dari $0,05(0,002<0,05)$. Nilai koefisien regresi positif menunjukkan hubungan yang searah antara tarif progresif dengan kepatuhan wajib pajak kendaraan bermotor di Kabupaten Bangli. Semakin tinggi dan adil tarif progresif maka tingkat kepatuhan wajib pajak dalam membayarkan pajaknya semakin tinggi.

Hipotesis penelitian ini mendukung teori atribusi yang mejadi landasan teori pada penelitian ini yaitu bahwa seseorang dalam menentukan tingkat kepatuhannya dapat dipengaruhi oleh faktor ekternal, yaitu faktor yang berasal dari luar diri wajib pajak yang dalam hal ini adalah tarif progresif, serta mendukung Theory of Planned Behavior yang menyatakan bahwa perilaku indivitu untuk patuh pada ketentuan perpajakan ditentukan oleh niat. Niat tersebut muncul dari dalam diri wajib pajak yang dapat menjadi faktor yang menentukan seseorang untuk berperilaku.“Hasil penelitian ini sejalan dengan penelitian yang dilakukan oleh Wisnu dan Made Kembar (2015) yang menemukan hasil bahwa tarif progresif mempengaruhi kepatuhan wajib pajak dalam membayar pajak. Serta hasil penelitian yang kemukakan oleh Ananda (2015) dan Prawegis (2016) bahwa tarif perpajakan berpengaruh pada kepatuhan wajib pajak UMKM. Semakin besarnya tarif progresif yang ditetapkan, dapat meningkatkan kepatuhan wajib pajak, karena apabila wajib pajak terlambat dalam membayar pajak maka semakin besar jumlah pajak yang harus dibayarkan pada hari berikutnya karena dikenakannya denda berdasarkan jumlah pajaknya ditambah lagi dengan dibebankannya tarif progresif apabila WP memiliki kendaraan lebih dari satu. 
Wajib pajak yang memiliki lebih dari satu kendaraan tetap patuh dalam membayar pajak walaupun ditetapkannya tarif progresif selama tarif yang ditetapkan adil dan tidak terlalu memberatkan wajib pajak. Hal ini mendukung teori atribusi yang digunakan pada penelitian ini bahwa seseorang dalam menentukan tingkat kepatuhannya dapat dipengaruhi oleh faktor ekternal dalam hal ini adalah tarif progresif.

Hipotesis kedua penelitian ini menyatakan bahwa kualitas pelayanan berpengaruh positif pada kepatuhan wajib pajak kendaraan bermotor di Kabupaten Bangli. Hasil pengujian dengan menggunakan regresi linier berganda sejalan dengan hipotesis yang dirumuskan, menunjukkan bahwa tarif progresif berpengaruh positif pada kepatuhan wajib pajak kendaraan bermotor di Kabupaten Bangli. Nilai regresi menunjukkan nilai koefisien positif sebesar 0,086 dengan nilai signifikansi sebesar 0,000 yang lebih kecil dari $0,05(0,000<0,05)$. Nilai koefisien regresi positif menunjukkan hubungan yang searah antara kualitas pelayanan dengan kepatuhan wajib pajak kendaraan bermotor di Kabupaten Bangli. Semakin tinggi dan baik kualitas pelayanan yang diterapkan Kantor SAMSAT Bangli maka tingkat kepatuhan wajib pajak dalam membayarkan pajaknya semakin tinggi.

Hipotesis penelitian ini mendukung teori atribusi yang menjadi landasan teori pada penelitian ini bahwa seseorang dalam menentukan tingkat kepatuhannya dapat dipengaruhi oleh faktor eksternal, yaitu faktor yang berasal dari luar diri wajib pajak seperti situasi dan lingkungan sekitar yang dalam hal ini adalah kualitas pelayanan yang diberikan kantor SAMSAT Bangli, dan juga 
Luh Putu Cintya Wijayanti dan I Made Sukartha. Pengaruh...

mendukung Theory of Planned Behavior yang menyatakan bahwa perilaku indivitu untuk patuh pada ketentuan perpajakan ditentukan oleh niat. Niat tersebut muncul dari dalam diri wajib pajak yang dapat menjadi faktor yang menentukan seseorang untuk berperilaku.Hasil penelitian ini sejalan dengan penelitian yang dilakukan oleh Mustika (2013), Amanda (2013), Lisa dan Supadmi (2017) yang menyatakan bahwa kualitas pelayanan berpengaruh positif dan signifikat pada kepatuhan wajib pajak. Kualitas pelayanan sangat mempengaruhi kepuasan wajib pajak dalam membayarkan kewajibannya. Setiap wajib pajak pasti menginginkan pelayanan dan sarana prasarana yang memadai untuk menumbuhkan rasa nyaman dan senang saat membayar pajak. Hal ini dikarenakan membayar pajak memerlukan waktu yang cukup lama berkisar antara 30 menit sampat satu jam, maka dari itu kenyamanan dan kepuasan adalah hal yang paling diinginkan oleh wajib pajak.

Hipotesis ketiga penelitian ini menyatakan bahwa sosialisasi perpajakan berpengaruh positif pada kepatuhan wajib pajak kendaraan bermotor di Kabupaten Bangli. Hasil pengujian dengan menggunakan regresi linier berganda sejalan dengan hipotesis yang dirumuskan, menunjukkan bahwa sosialisasi perpajakan berpengaruh positif pada kepatuhan wajib pajak kendaraan bermotor di Kabupaten Bangli. Nilai regresi menunjukkan nilai koefisien positif sebesar 0,173 dengan nilai signifikansi sebesar 0,003 yang lebih kecil dari $0,05(0,003<0,05)$. Nilai koefisien regresi positif menunjukkan hubungan yang searah antara sosialisasi perpajakan dengan kepatuhan wajib pajak kendaraan bermotor di Kabupaten Bangli. Semakin baik dan sering dilakukan sosialisasi mengenai perpajakan di 
Kantor SAMSAT Bangli maka tingkat kepatuhan wajib pajak dalam membayarkan pajaknya semakin tinggi.

Hipotesis ini mendukung teori atribusi yang menjadi landasan teori pada penelitian ini bahwa seseorang dalam menentukan tingkat kepatuhannya dapat dipengaruhi oleh faktor eksternal, yaitu faktor yang berasal dari luar diri wajib pajak seperti situasi dan lingkungan sekitar yang dalam hal ini adalah sosialisasi perpajakan yang diberikan Kantor SAMSAT Bangli, dan juga mendukung Theory of Planned Behavior yang menyatakan bahwa perilaku indivitu untuk patuh pada ketentuan perpajakan ditentukan oleh niat. Niat tersebut muncul dari dalam diri wajib pajak yang dapat menjadi faktor yang menentukan seseorang untuk berperilaku.

Hasil penelitian ini sejalan dengan penelitian yang dilakukan oleh Widnyani (2016) dan Dharma (2014), Meggy dan Ery (2017) bahwa sosialisasi pepajakan berpengaruh positif dan signifikan pada kepatuhan wajib pajak. Dengan memperoleh sosialisasi perpajakan yang baik dan secara rutin maka dapat meningkatkan kepatuhan wajib pajak. Peraturan perpajakan yang berubah-ubah menyebabkan sosialisasi perpajakan sangat diperlukan. Dengan adanya sosialisasi, wajib pajak akan mengetahui berita-berita terbaru mengenai perpajakan yang akan mempermudah dalam membayar pajak sesuai dengan kebutuhannya masingmasing. Hal ini sesuai dengan teori atribusi yaitu kepatuhan wajib pajak dipengaruhi oleh faktor yang berada diluar diri wajib pajak.

Hipotesis keempat penelitian ini menyatakan bahwa pengetahuan perpajakan wajib pajak berpengaruh positif pada kepatuhan wajib pajak kendaraan 
Luh Putu Cintya Wijayanti dan I Made Sukartha. Pengaruh...

bermotor di Kabupaten Bangli. Hasil pengujian dengan menggunakan regresi linier berganda sejalan dengan hipotesis yang dirumuskan, menunjukkan bahwa pengetahuan perpajakan wajib pajak berpengaruh positif pada kepatuhan wajib pajak kendaraan bermotor di Kabupaten Bangli. Nilai regresi menunjukkan nilai koefisien positif sebesar 0,189 dengan nilai signifikansi sebesar 0,001 yang lebih kecil dari $0,05(0,001<0,05)$. Nilai koefisien regresi positif menunjukkan hubungan yang searah antara pengetahuan perpajakan wajib pajak dengan kepatuhan wajib pajak kendaraan bermotor di Kabupaten Bangli. Semakin tinggi pengetahuan yang dimiliki wajib pajak mengenai perpajakan maka tingkat kepatuhan wajib pajak dalam membayarkan pajaknya semakin tinggi.

Hipotesis ini mendukung teori atribusi yang menjadi landsan teori pada penelitian ini bahwa seseorang dalam menentukan tingkat kepatuhannya dapat dipengaruhi oleh faktor internal, yaitu faktor yang berasal dari diri wajib pajak dalam hal ini adalah pengetahuan perpajakan yang dimiliki wajib pajak, dan juga mendukung Theory of Planned Behavior yang menyatakan bahwa perilaku indivitu untuk patuh pada ketentuan perpajakan ditentukan oleh niat. Niat tersebut muncul dari dalam diri wajib pajak yang dapat menjadi faktor yang menentukan seseorang untuk berperilaku. Hasil penelitian ini sejalan dengan penelitian yang dilakukan oleh Icha Fjriana dkk (2014), Supadmi (2017) dan Siregar (2012) yang menyatakan bahwa pengetahuan perpajakan berpengaruh positif pada kepatuhan wajib pajak. Semakin banyaknya pengetahuan mengenai perpajakan yang dimiliki wajib pajak maka dapat meningkatkan kepatuhan, dengan banyaknya pengetahuan 
yang dimiliki wajib pajak akan memahami pentingnya membayar pajak dan apa manfaatnya bagi kesejahteraan.

\section{SIMPULAN}

Penelitian ini menguji pegaruh tarif progresif, kualitas pelayanan, sosialisasi perpajakan dan pengetahuan perpajakan wajib pajak pada kepatuhan wajib pajak kendaraan bermotor di Kabupaten Bangli. Lokasi penelitian ini adalah di Kantor SAMSAT Bangli dengan mengambil 397 WP sebagai sampel dari 58.287 jumlah populasi keseluruhan. Berdasarkan hasil dan pembahasan, simpulan ini dapat diuraikan sebagai berikut: 1). Tarif Progresif berpengaruh positif pada kepatuhan wajib pajak kendaraan bermotor di Kabupaten Bangli. Hal ini berarti semakin tinggi dan adil tarif progresif yang dikenakan kepada WP semakin tinggi juga tingkat kepatuhan Wajib Pajaknya; 2). Kualitas Pelayanan berpengaruh positif pada kepatuhan wajib pajak kendaraan bermotor di Kabupaten Bangli. Hal ini berarti semakin baik pelayanan yang diberikan oleh SAMSAT Bangli, semakin meningkat juga tingkat kepatuhan Wajib Pajaknya; 3). Sosialisasi perpajakan berpengaruh positif pada kepatuhan wajib pajak kendaraan bermotor di Kabupaten Bangli. Hal ini berarti semakin baik dan semakin sering dilakukannya sosialisasi mengenai perpajakan, semakin meningkat juga tingkat kepatuhan Wajib Pajak; 4). Pengetahuan Perpajakan Wajib Pajak berpengaruh positif pada kepatuhan wajib pajak kendaraan bermotor di Kabupaten Bangli. Hal ini berarti semakin tinggi pengetahuan seseorang mengenai perpajakan, semakin meningkat juga tingkat kepatuhannya. 
Berdasarkan kesimpulan yang telah diuraikan di atas maka saran yang dapat diberikan tentang pengaruh tarif progresif pada kepatuhan wajib pajak di kabupaten Bangli adalah sebesar 11 persen, ini artinya keadilan dalam menetapkan pajak progresif harus lebih ditingkatkan. Sebaiknya pemerintah penetapkan tarif progresif yang progresif yaitu kenaikan yang meningkat untuk menekan jumlah kendaraan bermotor yang ada di Indonesia. Dengan berkurangnya jumlah kendaraan bermotor maka dapat mengurangi tingkat kemacetan dan polusi udara.

Pengaruh kualitas pelayanan pada kepatuhan wajib pajak kendaraan bermotor di kabupaten Bangli adalah sebesar 8,6 persen, ini artinya Kantor SAMSAT Bangli harus dapat meningkatkan kualitas sarana dan prasarana Kantor SAMSAT Bangli seperti kualitas gedung, teknologi yang digunakan, ruang tunggu dan tempat parkir. Selain itu sikap petugas Kantor SAMSAT Bangli juga harus ditingkatkan. Petugas seharusnya bersikap baik dan sopan kepada wajib pajak, dapat memberikan informasi yang jelas dan lengkap kepada wajib pajak serta dapat memberikan bimbingan kepada wajib pajak tentang peraturan perpajakan kendaraan bermotor.

Pengaruh Sosialisasi perpajakan pada kepatuhan wajib pajak kendaraan bermotor di Kabupaten Bangli adalah sebesar 14,6 persen, ini artinya Kantor SAMSAT Bangli harus dapat meningkatkan frekuensi dan kejelasan dalam melakukan sosialisasi perpajakan. Sebaiknya kantor samsat Bangli dapat memberikan sosialisasi dengan memberikan brosur mengenai perpajakan pada saat Wajib Pajak membayarkan pajak kendaraannya.Semakin sering dan jelas 
dilakukan sosialisasi, maka Wajib Pajak akan mengetahui informasi-informasi terbaru mengenai perpajakan.

Pengaruh pengetahuan perpajakan Wajib Pajak adalah sebesar 22,2 persen, ini berarti Kantor SAMSAT Bangli harus dapat meningkatkan pengetahuan perpajakan wajib pajaknya, misalnya dengan memberikan jawaban yang sesuai dari setiap informasi yang ditanyakan oleh wajib pajak, sehingga wajib pajak menjadi tahu akan pentingnya membayar pajak, dan ketentuan-ketentuan yang berlaku dalam perpajakan.

\section{REFERENSI}

Ajzen, Icek. 1991. The Theory of Planned Behavior. Organizational Behavior and Human Decision Processes, 5, pp. 179-211

Ali, M. M., Cecil, H. W., and Knoblett, J. A.2001. The Effect Of Tax rates and Enfoercement Policies on Tax Payer Compliance. A Study of selfEmployed Tax Payer. Antlantic Economic Journal. 29 (2): June.

Amanda, R. Siswanto dan I Ketut Jati 2013. Faktor-faktor Yang Mempengaruhi Kepatuhan Wajib Pajak Dalam Membayar Pajak Kendaraan Bermotor di Denpasar.E-Jurnal Akuntansi Universitas Udayana,2(3).

Bahl, Roy W., \& Linn, Johannes F. 1992. Urban Public Finance In Developing Countries. New York: Oxford University Press

Chau, Liung. 2009. A Critical Review of Fisher Tax Compliance Model (A Research Syntesis). Journal of Acconting and Taxation, 1(2), pp: 34-40.

Danuta, A. Nitecki. 1997. Measuring Service Quality. Journal of Marketing. Associate University Librarian, Yale University Library.

Dharma, Esa Gede dan Ketut Alit Suardana. 2014. Pengaruh Kesadaran Wajib Pajak, Sosialisasi Perpajakan, Kualitas Pelayanan Pada Kepatuhan Wajib.E-Jurnal Akuntansi Universitas Udayana. 6(1), h340-353

Dorasamy, Nirmala. 2011. Personal Income Tax Administrative Reforms: Enhancing Tax Collection by the South African Revenue Services (SARS). African Journal of Business Management, 5(9), pp: 3711-3722. 
Feld, L. P. and Frey, B. S., 2007, "Tax Compliance as the Result of Psychological Tax Contract: The Role of Incentives and Responsive Regulation". Volume 29, Issue 1, LAW \& POLICY.

Fjeldstad O, Schulz-Herzenberg C. and Hoem Sjursen I. 2012. People's Views of Taxation in Africa: A journal of Research on Determinants of Tax Compliance, ICTD Working Paper 8.

Fuadi. 2013. Pengaruh Kualitas Pelayanan Petugas Pajak, Sanksi Perpajakan dan Biaya Kepatuhan Pajak Terhadap Kepatuhan Wajib Pajak UMKM. EJournal Tax \& Accounting Review, 1(1), h20.

Ghozali, Imam. 2016. Aplikasi Analisis Multivariate dengan Program SPSS. Badan Penerbit Universitas Sumatera Diponegoro: Semarang

Harryanto, Marisa dan Agus Arianto Toly. 2013. "Pengaruh Wajib Pajak, Kegiatan Sosialisasi Perpajakan, Pemeriksaan Pajak terhadap Penerimaan Pajak Penghasilandi KPP Pratama Surabaya Sawahan".Tax dan Accounting Review. 1(1), h124-135.

Heenkenda, Shirantha. 2016. Readiness To Retirement Planning of Estate Sector Employees In Sri Lanka. Journal.University of Sri Jayawardenapaura.

Hidayat dan Nugroho. 2010. Studi Empiris Theory Of Planned Behavior dan Pengaruh Kewajiban Moral Pada Perilaku Ketidakpatuhan Pajak Wajib Pajak Orang Pribadi. Jurnal Akuntansi dan Keuangan, 12(2), h82-93.

Ilyas, Wirawan dan Richard Burton. 2010. Hukum Pajak. Edisi Revisi. Jakarta: Salemba Empat

James, S dan C. Alley. 2004. Tax Complience, Self Assesment and Tax Administration. Journal of Finance and Management in Public Service. 2(2), pp:27-42

Layata, S. \& Setiawan, P.E., 2014. Pengaruh Kewajiban Moral, Kualitas Pelayanan, Pemeriksaan Pajak dan Sanksi Perpajakan Pada Kepatuhan Wajib Pajak Badan.E-Jurnal Akuntansi Universitas Udayana.9(2).

Marti, Lumumba Omweri. 2010. Tax Payer's Attitude and Tax Complience.African Journal of Bussiness and Management, 1.Behaviour in Kenya.

Mustika, Utama I Wayan. 2013. Pengaruh Kualitas Pelayanan, Sanksi Perpajakan dan Biaya Kepatuhan Terhadap Kepatuhan Wajib Pajak.E-Journal Akuntansi. 2(2). 
Noormala, Sheikh, Obid. 2008. Voluntary compliance: tax education preventiv, Journal International Conference on Bussiness and Economy Constanta Romania, International Islamic University Malaysia.

Nova Kristanty, Siti Khairani dan Icha Fajriana. 2014. Pengaruh Pengetahuan Wajib Pajak, Tarif Pajak, dan Penyuluhan Pajak Terhadap Tingkat Kepatuhan Wajib Pajak Badan di Kantor Pelayanan Pajak Madya Palembang. Jurnal Jurusan Akuntansi. STIE MDP Palembang

Palda, Filip dan Jan Hanousek. 2002. Quality of Government Services and the Civic Duty to Pay Taxes in the Czech and Slovak Republics, and other Transition Countries.

Palil, M Rizal. 2005. Does Tax Knowledge Matter in Self Assessment System? Evidence From Malaysia Tax Administrative.The Journal of American Academy of Business. Cambrige, (2).

Pranata, Aditya, dan Ery Setiawan. 2015. Pengaruh Sanksi Perpajakan, Kualitas Pelayanan dan Kewajiban Moral pada Kepatuhan Wajib Pajak.E-Jurnal Akuntansi Universitas Udayana,10(2), h456-473.

Putra, Adi. 2009. Pengaruh Kualitas Pelayanan Terhadap Kinerja Kerelasian Nasabah.Jurnal Ekonomi Bisnis, 14(2), h151-160, Malang: Fakultas Ekonomi Universitas Negeri Malang.

Razak, Abubakari Akbar dan Christoper Jwayire Adafula. 2013. Evaluating taxpayers, attitude and its influence on tax compliance decisions in Temale Ghana. Journal of Acounting abd Taxation, 5(3), pp:48-57 september 2013.

Richardson, G, 2006. Determinants of Tax Evasion: A Cross Country Investigation. Journal of Accounting, Auditing and Taxation 15, pp150-169.

Rizki Amalia, Topowijono, Dwiatmanto. 2016. Pengaruh Pengenaan Sanksi Administrasi Dan Kesadaran Wajib Pajak Terhadap Tingkat Kepatuhan Wajib Pajak Kendaraan Bermotor. Jurnal Administrasi Bisnis. Fakultas Ilmu Administrasi Universitas Brawijaya Malang.

Santika, K.A. 2015. Pengaruh Kesadaran Wajib Pajak, Kualitas Pelayanan, dan Sanksi Perpajakan pada Kepatuhan Wajib Pajak Air Tanah di Dinas Pendapatan Kota Denpasar. E-Jurnal Akuntansi Universitas Udayana. 12(3), h656-670.

Sentanu dan Ery. 2016. Pengaruh Kualitas Pelayanan, Kewajiban Moral Dan Sanksi Perpajakan Pada Kepatuhan Wajib Pajak Hotel. E-Jurnal Akuntansi Universitas Udayana.16 (1), h 306-332. 
Siregar, Yuli. Anita. Saryadi, dan Listyoni, Sari. 2012. Pengaruh Pelayanan Fiskus dan Pengetahuan peraturan perpajakan terhadap Kepatuhan Wajib Pajak. Jurnal Ilmu Administrasi Bisnis, 1(2): h1-9.

Sulistianingrum. 2009. Pengaruh Kualitas Pelayanan Administrasi terhadap Tingkat Kepatuhan Wajib Pajak (Studi Kasus pada KPP Pratama Jakarta Setiabudi Satu. Fakultas Ekonomi Universitas Pembangunan Nasional "Veteran" Jakarta

Supriyati, dan Nur Hidayati. 2008. "Pengaruh Pengetahuan Wajib Pajak dan Persepsi Wajib Pajak”. Jurnal Akuntansi \& Teknologi Informasi. 7(1), h1011.

Susilawati, K. 2013. Pengaruh Kesadaran Wajib Pajak,Pengetahuan Pajak,Sanksi Perpajakan dan Akuntabilitas Pelayanan Publik Pada Kepatuhan Wajib Pajak Kendaraan Bermotor. E-Jurnal Akuntansi Universitas Udayana.4(2)h345-357.

Syahril, Farid. 2013. Pengaruh Tingkat Pemahaman Wajib Pajak Dan Kualitas Pelayanan Fiskus Terhadap Tingkat Kepatuhan Wajib Pajak PPh Orang Pribadi (Studi Empiris Pada KPP Pratama Kota Solok).Jurnal Universitas Negeri Padang.

Tamanda Kyun dalam Marziana, et al. 2009. Perceptions of Taxprayers with Level of Compliance: a Comparison in the East Coast Region, Malaysia Accounting Department, College of Business Management and Accounting, Universiti Nasional, Malaysia.

Waluyo, dan Wiryawan B Ilyas. 2010. Perpajakan Indonesia. Jakarta: Salemba Empat

Winerungan, Lidya Oktaviane. 2013. Sosialisasi Perpajakan, Pelayanan Fiskus dan Sanksi Perpajakan terhadap Kepatuhan WPOP di KPP Manado dan KPP Bitung. Jurnal EMBA. 1(3) h960-970.

Wisnu, Ngurah, Made Kembar, dan Purbadarmaja. 2015. Pengaruh Pajak Progresif Terhadap Perilaku Konsumtif, Basis Pajak, Kepatuhan Wajib Pajak Dan Pendapatan Daerah Provinsi Bali. E-Jurnal Ekonomi dan Bisnis Universitas Udayana. 4(12). 